\title{
Reflections on the Proposal to Introduce a Term Limit for Elected Officials
}

Effects and Implications

\begin{abstract}
The problem of the lack of "generational replacement" in Poland is particularly evident on the local self-government level. For years, there has been an ongoing public debate on the adoption of legal solutions introducing term-limits for the office of commune head, mayor and president of the city. Politicians of Law and Justice returned to their idea from 2005 and, shortly before the local elections of 2018, decided to prepare new regulations in this respect. They argued that the adopted solutions create real prospects for implementing projects by young politicians and activists. However, the issue was hotly debated and the initiators' motives were put into question. There is no doubt that a two-term limit in local selfgovernment units has always stirred up emotions. A lot of self-government officials perceive it as a regulation which violates the provisions of the Constitution of the RP. The aim of this paper is to present the public debate on the adopted solutions and discuss their assumptions.
\end{abstract}

Keywords: Political system, Poland, elections, term limit, local government

In democratic legal systems there is a wide array of instruments which significantly determine the composition of future parliaments. Owing to appropriate provisions in election law, political parties can strengthen their position in relation to earlier forecasts. The temptation to introduce changes to the existing laws tends to be bigger when the date of elections approaches. It is obvious that only those parties which enjoy the majority of seats in the parliament enjoy the possibility of re-establishing the principles of the forthcoming competition. Rational legislators need to have a sufficiently long period for reflection and discussion. This leeway helps to cool emotions and look at planned solutions from a broader perspective. New opportunities to listen to various opinions and standpoints appear and 
experts from outside political parties have a chance to express their views. It has become a common practice in the Polish political reality that election campaigns are accompanied by legal bargaining. The borders of electoral districts are changed as are vote counting methods and voting procedures, with the aim to make them as favorable to the party presently in rule as possible.

Another issue constantly recurs in the Polish political debate. This frequently raised problem concerns the lack of "generational replacement". This phenomenon is particularly evident on the self-government level. We should definitely consider the form of new regulations, which would make it possible for young politicians to present their views and concepts to a wider spectrum of voters. The fact that a proposal to limit the term of office for people performing public duties is submitted during the election campaign throws the initiators' motives into question. Is this really about injecting new blood into new elites, breaking with the past and destroying local networks of connections? Do the initiators aim to delegate authority to young, competent and well-educated persons or is this a mere attempt to find important positions for their own cadres? These questions should be answered by analyzing what politicians, self-government officials and representatives of the doctrine have to say.

The proposal to make changes and introduce a term limit for local government offices was first made by Law and Justice after this party won the parliamentary election of 2005. The politicians of Law and Justice submitted a draft act which limited the right to stand for election by stipulating that a person can hold the office of president, mayor or commune head for the maximum period of two terms. According to the initiators, this solution could help to destroy networks of family and social connections which were omnipresent in self-government units.

In 2006, Marek Kuchciński, one of Law and Justice leaders, often emphasized that a term limit in local governments was not a completely new idea. This concept was first proposed during the work on changes in election law in the late 1990s. The idea returned in the Sejm of the $4^{\text {th }}$ term of office, when changes in self-government acts were discussed in the Local Self-Government and Regional Policy Committee (Kacprzak, 2006). Another important politician of Law and Justice, Przemysław Gosiewski, pointed out that the then binding election law was conducive to the so-called networks. In his opinion, his party's concept was not about restricting citizens' voting rights. The initiators assured that they did not intend to make room for their fellow party members in local governments, but that their only aim was to respect the principles of democracy. What is more, low voter turnout cemented old networks, in which, from the 1970s, the same people had held the office of commune head (earlier "naczelnik", currently called "wójt" in Polish) (Kacprzak, 2006).

The chairman of Law and Justice, Jarosław Kaczyński, argued that the introduction of limits concerning the term of office of commune heads is not tantamount to an attack on self-government, because "self-government units may function under such limitations as well as without them” (Serwis Samorządowy PAP, n.d.). 
The proposal to introduce a limit of two terms for persons holding the office of commune head, mayor or president of the city met with severe criticism on the part of self-government officials, who were outraged at the prospect. The solution proposed by Law and Justice was called "an attack on democracy", "cheap populism" and "limiting citizens' voting rights". It was stressed that the implementation of a new election regulation would mean that - referring to the case of Silesia - about $80 \%$ of people with long professional experience, also in local government work, would have no chance of being re-elected.

At the $19^{\text {th }}$ Nationwide Conference of Commune Heads, Mayors, Presidents, Starosts and Marshals of Poland held in Poznań on June 27-28, 2006, the representatives of the Union of Polish Metropolises, the Union of Polish Towns, the Association of Rural Communes of the RP, the Union of Polish Cities, the Union of Polish Counties, and the Union of Polish Provinces, expressed their opinion on the proposed changes in self-government election laws and in the system of self-government units. Self-government officials stated unanimously that the new regulation was the explicitly opportunistic solution. It was not based on any substantive arguments and was strictly related to the approaching local elections (Ogólnopolska Konferencja Wójtów..., 2006).

On February 20, 2006, the Union of Rural Communes of the Republic of Poland (ZGWRP - Zwiazek Gmin Wiejskich Rzeczypospolitej Polskiej) presented its position on the Law and Justice's concept. The representatives of the Union expressed their concern and outrage at the proposed introduction of regulations limiting the time of holding the office of commune head, mayor and president of the city to two terms. They believed that the new law would make it impossible for citizens to elect candidates in an unrestricted way and the best local government officials, who enjoyed social legitimacy, would be "banished" without any reasonable arguments. ZGWRP representatives agreed that it was an open attack on democracy and civil liberties guaranteed by the Constitution of the RP. In the adopted statement, it was emphasized that "Polish communes were particularly successful in the areas where the continuity of the executive power is ensured. (...) In order to establish the directions of development, it is necessary to obtain knowledge of the developmental potential of a commune, its inhabitants and possibilities of acquiring external resources to co-finance planned investments". Local government officials argued that the ruling party's new idea was just an attempt to make profit, a method of seeking additional resources for the implementation of the government's strategic goals at the cost of significantly reducing the local communities' chances of development (Poznański, 2006).

The politicians of opposition parties (Civic Platform, Polish Peasants' Party, Democratic Left Alliance and Self-Defence) were unsparing in their criticism of Law and Justice's concept. They reminded that it was not a new idea, and this solution had been proposed and discussed many times in the past. It had never won wide recognition, though. Bronisław Komorowski from Civic Platform argued: "Nowhere in Europe are there any term limits concerning offices in local governments and no country has introduced restrictions of this kind" (“Komorowski krytykuje...", 2006). In his opinion, if Law and Justice implemented 
this idea, people with big experience and knowledge, respected by the society, would be deprived of the possibility of working in self-government institutions. Democratic Left Alliance deputy, Witold Gintowt, believed that "term limits were just a cover for removing competition from local governments, from where the ruling party had no chance of winning elections (“Komorowski krytykuje..., 2006).

Waldemar Pawlak, the then chairman of Polish Peasants' Party, stressed that the introduction of "term limits for commune heads, mayors and presidents of the city violates constitutional rights and freedoms. It leads to the political elimination of the most effective and righteous people, who are subject to the evaluation and verification by the society in elections" (Waldemar Pawlak. Energia dla Polski, n.d.). According to Pawlak, quite the opposite steps need to be taken in order to help Polish local government units raise EU funds and make them stronger, both legally and financially" ("PiS-u zamach na samorząd?", 2006).

Janusz Piechociński accurately remarked that a trend of centralization is a very negative phenomenon in Polish politics. Self-government and self-dependence in action needs support on a regular basis. The development of communities has to be constantly stimulated rather than being controlled and hampered. It is out of the question that statutory modifications in the field of local self-government are needed. However, they certainly do not concern limiting the right to be re-elected for commune head, mayor or president of the city" ("PiS-u zamach na samorząd?", 2006).

The majority of the representatives of the doctrine, sociologists and political scientists spoke in a similar vein. They pointed out that free local self-government is one of Poland's biggest achievements in recent years. What will be the consequence of the introduction of the new solution will be the politicization of local elections and, thus, the politicization of self-government. According to Marek Mączyński, it is voters' decision rather than the legislators' initiatives that should be the foundation for introducing any changes in "local elites" (Kacprzak, 2006).

Michał Kulesza, the man behind the new administrative division of Poland introduced by Jerzy Buzek's cabinet, also severely criticized Law and Justice's concept. He said that, for the good of the state, it would be more useful to introduce a two term limit for parliamentary seats ("PiS-u zamach na samorząd?", 2006).

The expert opinion prepared by Professor Jerzy Regulski ${ }^{1}$, who is an unquestionable authority in the field of self-government, shows that holding the office of commune head,

1 Chairman of the Polish Foundation for Support to the Local Democracy is one of the creators of local self-government in the 3rd Republic of Poland. In the years 1989-91 he led parliamentary work on self-government reform package, and then, acting as the Government's Plenipotentiary for the Reform of Territorial Self-Government, he coordinated its implementation. From 1992 to 1997, he was the Permanent Representative of Poland to the Council of Europe in Strasburg. In the years 1998-1999 - Chairman of the Council for the Political Reforms of the State appointed by the Prime Minister of the Republic of Poland. An eminent expert in self-government and urban issues. He has published more than 200 books and dissertations and gave lectures at 78 universities. 
mayor or president of the city for several consecutive terms does not actually cause any problems. Universal direct elections held every four years are in fact a sufficient and effective mechanism for verifying self-government officials' achievements by the society (Regulski, 2006). Limiting the number of terms may prove to be counterproductive and the consequences may be as follows:

a. legal-constitutional - referring to limiting the right to stand for election for the people who have held the office of commune heads, mayors and presidents of the city for two consecutive terms, as well as limiting citizens' right to vote freely. The Constitution of the RP explicitly adopts the principle of the equality of every citizen. Depriving someone of the right to be elected on account of the previous public activity would be a violation of the constitutional principle of equality. The proposed statutory changes led to eliminating people who have been successful in their self-government activity, which may consequently hamper the development of civil society;

b. social-civil - what is the essence of local self-government is to let local communities make their own decisions concerning the issues that directly concern them;

c. functional - limits concerning the terms of office may cause severe organizational chaos. They will destabilize the activity of local government institutions. In this context, it seems justifiable that the terms of office of commune heads, mayors and presidents of the city should be extended because of the implementation of long-term projects co-financed by the European Union. It is thus logical that it is the author of the programme who should be responsible for putting it into life. Changing commune heads while such projects are in progress would be very risky (Regulski, 2006).

Jerzy Regulski criticized Law and Justice's proposal to introduce term limits in local self-government, adding a few other important arguments. For example, he claimed that the new solution:

- lacks substantive arguments, so it is unnecessary,

- would be a violation of civil rights,

- would be incomprehensible to the society since it is difficult to understand why good and proven people would be eliminated,

- would undermine the foundations of self-government, consisting in local communities' right to elect people who will safeguard local interests,

- would reduce the quality of local administration (Regulski, 2006).

Norbert Honka, an expert in the field of local self-government from Opole University spoke in a similar vein. He pointed out that politicians should not use statutory regulations to change efficient self-government officials who are subject to the assessment by voters. According to Honka, "new power often means new staff, inexperience and wasting time training new people. After all, those who are negatively evaluated are eliminated in elections" (Leszczyński, 2007). 
Law and Justice's proposal from 2006 did not win much support. Just before the elections, questions were raised about the true intentions of the ruling party's politicians (Kacprzak, 2006).

Finally, in the face of such strong criticism, Law and Justice abandoned its regulation, which most of the public believed was the ruling party's attack on local self-government.

After the parliamentary election of 25 October 2015, won by Law and Justice, the concept of introducing a two-term limit in local self-government have re-emerged. The proposal has become the subject of debate in a special committee appointed for amending the Election Code. After a seven day debate, the deputies of the ruling party, despite the criticism and objections raised by the opposition (Civic Platform, Modern, Polish Peasants' Party, Kukiz'15), voted for the adoption of this solution. Finally, after the Election Code was amended on 31 January 2018 (Ustawa z dnia 5 stycznia 2011 r. Kodeks wyborczy, 2011), a two-term limit for commune heads and city mayors and presidents was introduced and was entered into force after the local elections in October 2018 (Grochowski, 2018; (pm), 2018; PAP, 2017). Under art. 11\$ 4 of the Election Code, "A person who has already been elected twice for the commune head in the elections called under art. $474 \$ 1$, has no right to be elected for the head of the same commune". Under Art. 5, Par. 6 the code regulations concerning commune head also apply to mayor and president of the city" (Ustawa $\mathrm{z}$ dnia 5 stycznia 2011 r. Kodeks wyborczy, 2011).

The initiators of these new election regulations argue that the two-term limit will bring positive effects by reducing and preventing a number of pathologies, such as "the alienation of people holding offices for a few consecutive terms and the formation of - due to long incumbency - local interest groups (coteries)". The drafters believe that "owing to limiting the number of terms of commune heads, mayors and presidents of the city, political elites on the local level will be replaced on a regular basis, and closed, fossilized political-businesssocial networks, which have monopolized local power for several years or even decades, will be split". They also indicated that they "obviously do not assume that the rule of the same person in a commune always leads to pathologies, but there is no doubt it increases the risk of the appearance of negative phenomena". The initiators of the new act emphasized that "the right to hold the office of commune head, mayor or president of the city is not an absolute constitutional right and may be specified by statute by statute (Art. 169, Par. 3 of the Constitution). It is necessary, however, to maintain a right of access to the public service on the principle of equality (Art. 60) and the principle of a democratic state ruled by law (Art. 2)" (Projekt ustawy o zmianie..., 2017).

The introduction of such far-fetched amendments to election law just a few months before local elections was severely criticized by a number of constitutionalists, theoreticians and practitioners of the election law, as well as by representatives of non-governmental organizations (Godlewski, 2017). According to experts from the Stefan Batory Foundation, the amendment of the Election Code, which was hastily adopted without proper debate, poses a threat to the transparency of the election process (Skrzydło \& Chmaj, 2015; Nohlen, 
2004; Rączkiewicz, 2014). It also negatively affects political pluralism. A similar opinion was expressed by representatives of the National Electoral Commission and the Polish Ombudsman. It was pointed out that changes in the rules of the election process and in the local self-government system, made for no justifiable reasons and introduced just before the elections, are an infringement on the principles of democracy, the rule of law and the existing standards of a reasonable legislative process. A number of reputed authorities in the field of party systems, such as Mikołaj Cześnik, Jarosław Flis, Ada Gendźwiłło, Anna Materska-Sosnowska, Bartłomiej Michalak, and Andrzej Rychard, all believe that it may lead to negating "the legitimacy and binding character of future local, parliamentary and presidential elections” (Dereszyński, 2018; see also: Michalak, 2009, pp. 165-186).

The introduction of a two-term limit in self-government offices brings out strong emotions. A number of self-government officials perceive it as an act violating the fundamental law as it limits the right to stand in and vote in elections. According to the President of Dąbrowa Górnicza, Zbigniew Podraza, this solution is unconstitutional and purely demagogical. He argues that "the right of electability itself makes it possible to replace local government officials. (...) In each election, approximately $30 \%$ of them are replaced. It is the citizens who make decisions here and it is their votes that are the best possible test for local politicians. If their work is negatively assessed, they will not be elected again" (KDS, 2018). Marek Olszewski, the Head of the commune of Lubicz and also the Chairman of the Association of the Rural Communes of the Republic of Poland, said "There are a lot of multi-term rural commune heads in Poland; some of them have performed this function since 1990. This does not prove the lack of democracy. They do not vote for themselves. It is commune residents who elect them. Looking for a new commune head after 10 years just because the law says so is not a good solution. All the more so because a great many of them are young, ambitious people with a clear vision of changes that they want to put into life. Thus, why should we look for a new candidate if the current commune head has only started his job and is gaining experience? There are no schools for commune heads in Poland. They have to learn how to manage a commune on their own, and for this - just like for everything - time is needed. (...) The introduction of this solution will particularly harm heads of rural communes, in which competition for power is often a lot smaller" (Domagała-Szymonek, 2018).

The representatives of the Union of Polish Cities took the same position. They announced that they were thinking of launching an initiative to call a referendum concerning the introduction of a two-term principle, which would refer to all elected officials (Żółciak, 2018).

During a debate in the commission, Waldy Dzikowski, deputy from Civic Platform, said that a two-term principle will not eliminate pathologies in local government units; quite the opposite, it will give rise to other negative phenomena. In his opinion, "no reasonable and sagacious person will make a decision to abandon their job as a barrister, notary or general practitioner, etc. It is those who are already retired who will decide to spend eight years in public service. (...) It will be a negative, totally negative selection”. Dzikowski added that 
the final years of the second term will be a time of stagnation" (Kancelaria Sejmu. Biuro Komisji Sejmowych, 2017).

In response to these accusations, Law and Justice's politicians argued that the new regulation is consistent with the fundamental law and what is more it is valuable because it reduces the occurrence of negative phenomena such as nepotism or manipulations. It also prevents the monopolization of power on the local level.Zbigniew Cymański said: "although I do respect local self-government officials, I do not share their concern, because the new election law raises democratic standards" (Dyląg, 2018).

Statutory regulations limiting people's choice may only bring negative results and lead to local conflicts (Dyląg, 2018). Marek Sowa, deputy from Modern, stressed that the amendment of the Election Code passed thanks to the votes of the ruling party's MPS is rather a vague concept. In his view, such "an act will not contribute to the formation of civil society. Neither will it encourage citizens to take part in elections" (Dyląg, 2018). What is important, voters should have the consolidated knowledge of the voting system. What is more, as Jerzy Regulski rightly noted,"the process of building authority in rural communes takes time, and authority itself does not depend on any legal regulations" ("PiS-u zamach na samorząd?", 2006).

Having in mind the arguments that the advocates and opponents of a two-term limit for self-government officials raise in the public debate, a question should be asked as to what extent long-term experience and trust from residents is important. What obviously helps to improve the efficiency and quality of work is a politically neutral decision-making process. Politicians should really trust citizens. Ill-considered and over-hastily implemented reforms make people losing trust in politicians and becoming alienated in public space. Changes in the delicate electoral matter, of such a huge scale and importance, should be preceded with in-depth studies. Reforms of the election system should meet democratic standards, both regarding the proposed changes and the process of preparation and introduction itself. The direction of such reforms should be established on the basis of past achievements and experiences rather than serving temporary party interests and political rivalry (Rymarz, 2006, p. 6). In the Act of 8 March 1990 on local self-government (Dz.U 2016 poz. 446, 1579) in Art. 26 after Par. 2a, Par. 2b was added in the wording: "One person shall hold the office of commune head (mayor, president of the city) in a given commune for no more than two terms. The moment commune head (mayor, president of the city) assumes office in a commune for the second term, they lose a right to stand in election for the office of commune head (mayor, president of the city) in the next election".

\section{References}

Kacprzak, I. (2006, February 14). "Nowy pomysł Prawa i Sprawiedliwości na wybory samorządowe". Dziennik Zachodni.

Serwis Samorządowy PAP (n.d.). Retrieved from: www.samorzad.pap.pl. 
Ogólnopolska Konferencja Wójtów, Burmistrzów, Prezydentów, Starostów i Marszałków (2006, February 20). Retrieved from: http://www.poznan.pl/mim/info/news/xix-ogolnopolska-konferencja-wojtowburmistrzow-prezydentow-starostow-i-marszalkow,15241.html.

Poznański, M. (2006, March 13). “Stanowisko w sprawie propozycji wprowadzenia dwu-kadencyjności dla pełnienia funkcji wójta, burmistrza i prezydenta”. Związek Gmin Wiejskich Województwa Podlaskiego. Retrieved from: http://zgwwp.org.pl/bez-kategorii/stanowisko-w-sprawie-propozycji-wprowadzeniadwu-kadencyjnoci-dla-penienia-funkcji-wojta-burmistrza-i-prezydenta/.

“Komorowski krytykuje pomysł PiS” (2006, February 13). Dziennik Bałtycki.

Waldemar Pawlak. Energia dla Polski (n.d.). Retrieved from: www.pawlak.pl.

"PiS-u zamach na samorząd?" (2006, April). Samorząd, 1(50). Retrieved from: www.wiesciwyborcze.pl.

Regulski, J. (2006, February 22). Możliwości i konsekwencje, wynikajace z wprowadzenia przepisów, ograniczajacych sprawowanie funkcji wójta, burmistrza, prezydenta miasta do dwóch kadencji. Uwaga wstępna [expert opinion]. Warsaw.

Leszczyński, R. (2007, February 1). “Raz na wozie, raz pod wozem”. Tygodnik Lokalny.

Grochowski, K. (2018, April 9). "Wybory samorządowe w 2018 roku - nowe przepisy i zmiany ordynacji wyborczej”. Gazeta.pl Wiadomości. Retrieved form: http://wiadomosci.gazeta.pl/wiadomosci/7,1148 84,23236281,wybory-samorzadowe-w-2018-roku-nowe-przepisy-i-zmiany-ordynacji.html.

(pm) (2017, December 7). “Rząd PiS wprowadza dwukadencyjność wójtów, burmistrzów i prezydentów miast”. Onet Wiadomości. Retrieved from: https://wiadomosci.onet.pl/kraj/rzad-pis-wprowadzadwukadencyjnosc-wojtow-burmistrzow-i-prezydentow-miast $/ 7 \mathrm{~cm} 1 \mathrm{~m} 0 \mathrm{n}$.

PAP (2017, December 15). “Sejm uchwalił zmiany w ordynacji wyborczej; będzie dwukadencyjność w samorządach”. Polska Agencja Prasowa. Retrieved from: http://www.pap.pl/aktualnosci/ news, 1211407,sejm-uchwalil-zmiany-w-ordynacji-wyborczej-bedzie-dwukadencyjnosc-w-samorzadach.html.

Projekt ustawy o zmianie ustawy - Kodeks wyborczy oraz niektórych innych ustaw (2017, November 17). Druk nr 2023. Archiwum Osiatyńskiego. Retrieved from: https://archiwumosiatynskiego.pl/ images/2017/12/20231.pdf.

Godlewski, M. (2017, December 21). “Opinia Naczelnej Rady Adwokackiej do poselskiego projektu ustawy o zmianie - Kodeks wyborczy”. Adwokatura Polska. Retrieved from: http://www.adwokatura.pl/ admin/wgrane_pliki/file-20171221-opinia-u-kodeks-wyborczy-mec-godlewski-236-17-21659.pdf. Skrzydło, W., \& Chmaj, M. (2015). System wyborczy w Rzeczypospolitej Polskiej. Warszawa: Wolters Kluwer. Nohlen, D. (2004). Prawo wyborcze i system partyjny - o teorii systemów wyborczych. Warszawa: Wydawnictwo Naukowe "Scholar".

Rączkiewicz, M. (Ed.) (2014). Mechanizmy obietnic. Kampanie i systemy wyborcze na świecie. Łódź: Wydawnictwo Uniwersytetu Łódzkiego.

Dereszyński, T. (2018, January 23). “Ordynacja wyborcza do samorządu 2018. Gdzie są zagrożenia, wady, niezgodność z Konstytucją RP? Eksperci nie mają żadnych wątpliwości”. Polska. Retrieved from: http:// www.polskatimes.pl/fakty/polityka/a/ordynacja-wyborcza-do-samorzadu-2018-gdzie-sa-zagrozeniawady-niezgodnosc-z-konstytucja-rp-eksperci-nie-maja-zadnych-watpliwosci,12874370/.

Michalak, B. (2009). "Kierunki reformy systemu wyborczego na tle praktyki wyborczej w Polsce". Athenaeum. Polskie Studia Politologiczne, 21, pp. 165-186.

KDS (2018, January 18)."Zbigniew Podraza, prezydent Dąbrowy Górniczej: argumenty za dwukadencyjnością to demagogia”. Portal Samorzadowy. Retrieved from: http://www.portalsamorzadowy.pl/polityka-ispoleczenstwo/zbigniew-podraza-prezydent-dabrowy-gorniczej-argumenty-za-dwukadencyjnosciato-demagogia,102943.html. 
Domagała-Szymonek, K. (2018, January 18). "Marek Olszewski, prezes ZGW RP, o zmianach w ordynacji wyborczej, nowym rządzie, edukacji na wsi i recentralizacji Polski”. Portal Samorzadowy. Retrieved from: http://www.portalsamorzadowy.pl/polityka-i-spoleczenstwo/marek-olszewski-prezes-zgw-rpo-zmianach-w-ordynacji-wyborczej-nowym-rzadzie-edukacji-na-wsi-i-recentralizacji-polski,102881. html.

Żółciak, T. (2018, March 29). “Dwukadencyjność wciąż uwiera. Wraca pomysł referendum”. Gazeta Prawna. pl. Retrieved from: http://serwisy.gazetaprawna.pl/samorzad/artykuly/1114270,referendum-wsograniczenia-liczby-kadencji-w-samorzadach.html.

Kancelaria Sejmu. Biuro Komisji Sejmowych (2017, November 28). "Pełny zapis przebiegu posiedzenia Komisji Nadzwyczajnej do rozpatrzenia projektów ustaw z zakresu prawa wyborczego (nr 2)”. Sejm Rzeczypospolitej Polskiej. Retrieved from: http://orka.sejm.gov.pl/zapisy8.nsf/0/FA8EC67C63A829A FC12581EF00504C1C/\%24File/0259508.pdf.

Dyląg, B. (2018, January 16). Komentarze do prezydenckiego podpisu nowelizacji Kodeksu wyborczego. Portal Samorzadowy. Retrieved from: http://www.portalsamorzadowy.pl/polityka-i-spoleczenstwo/ komentarze-do-prezydenckiego-podpisu-nowelizacji-kodeksu-wyborczego,102859.html.

Rymarz, F. (2000). “Wstęp”. In F. Rymarz (Ed.), 10 lat demokratycznego prawa wyborczego w Polsce. Warsaw. Ustawa z dnia 5 stycznia 2011 r. Kodeks wyborczy. Dz.U. 2011 Nr 21 poz. 112. Sejm Rzeczypospolitej Polskiej. Retrieved from: http://www.sejm.gov.pl/prawo/kodeks/kodeks_wyborczy2018.pdf.

\section{Author}

\section{Joanna Marszałek-Kawa}

Nicolaus Copernicus University in Toruń, Faculty of Political Science.

Contact details: kawadj@box43.pl 